\title{
Competing Allies: Legal Pluralism, and Gendered Agency in Mumbai's Sharia Courts
}

Building upon participant observation in a women's sharia court in Mumbai, run by activists of an Islamic feminist movement in India, and its networks with similar alternative dispute resolution forums run by male qazis (non-state actors trained in Islamic law and Muslim personal law), this article explores the modalities of interaction between non-state actors who adjudicate Muslim personal law in India. It also delineates how gendered agency is shaped in these interactions. This article identifies three aspects of this interaction between male and female non-state actors: (1) everyday cooperation between male and female qazi despite their doctrinal differences; (2) the gradual assertion of female qazi in and through everyday cooperation with male qazi; and (3) institutional competition interlaced with everyday cooperation. I explore a range of interactions including contestation and collaborative contestation between non-state actors, a domain that has not been explored in existing scholarship on legal pluralism. I also draw attention to how we might think about women's agency in a legal pluralist context beyond a straightforward challenge to male authority and as it is forged at the intersection of individuals, interactions, and institutions. Through a critical exploration of women's agency, I show how women both inhabit and transform gender norms at an individual and institutional level in their interactions with non-state actors and institutions, expanding scholarship on legal pluralism and gender beyond reified "women's interests."

\section{INTRODUCTION}

A narrow serpentine by-lane off the Western Express Highway in Mumbai leads to the women's sharia court of the Bharatiya Muslim Mahila Andolan (BMMA; Indian Muslim Women's Movement). In this court, one of several alternative dispute resolution forums run by activists of the BMMA in India, only women can be qazis (non-state actors who adjudicate Muslim personal law in India). ${ }^{1}$ Nasreen Shaikh,

Sagnik Dutta, Jindal Global Law School, O. P. Jindal Global University, Sonipat, Haryana, India Emails: sdutta1@jgu.edu.in; dutta.sagnik@gmail.com

I would like to thank the editor and the six anonymous peer reviewers for their generous engagement and insightful comments. The fieldwork for this project was carried out during my doctoral studies supported by the Gates Cambridge Trust. Support was also provided by the fieldwork funds of the University of Cambridge.

1. I use the term "court" here as a shorthand for alternative dispute resolution forum. It is important to clarify at the outset that the Indian state neither officially recognizes any of these forums nor prohibits their functioning. Yet they play an important role in the adjudication of marriage, divorce, and the maintenance of Muslim communities within a legal pluralist framework of administration of Muslim personal law in India. They serve an important function for poor Muslim women who need a resolution for marital conflicts but find it difficult to access the formal legal system. Even in cases where women use the state courts, the 
a female qazi, adjudicates cases of marriage, divorce, and maintenance. ${ }^{2}$ Through informal negotiations with husbands, and using her networks with local lawyers, the police, and male qazis, Shaikh ensures that husbands pay maintenance payments and the dower (mehr) owed to each divorced woman. ${ }^{3}$ While this forum was ostensibly a part of the BMMA's efforts to challenge the predominance of male adjudicatory power in alternative dispute resolution forums that administer Muslim personal law in India, Shaikh has interacted regularly with Ibrahim, the local male qazi. She initially sent her clients to Ibrahim to get him to issue a talaq nama (a document recording the details of divorce such as maintenance, custody, reason for divorce, and so on) that endorses her decision. She gradually became more assertive as a woman qazi and insisted that clients did not change the terms and conditions of the divorce that were decided in the women's sharia court when they requested a talaq nama from Ibrahim. She started issuing her own talaq nama.

Shaikh and her colleagues also pursued their agenda at the dar-ul-qaza of the All-India Muslim Personal Law Board (AIMPLB), a body that contested the authority of female qazis in public debates on Muslim personal law. Activists of the BMMA accompanied women litigants to the dar-ul-qaza of the AIMPLB to help them procure a faksh-e-nikah (a form of divorce issued ex-parte to women when their husbands went missing) issued by the male qazi when their cases could not be resolved by the women's sharia court of the BMMA. At the court of the male qazi, activists encountered women who were dissatisfied with the way the male-dominated courts had handled their cases. Activists of the BMMA persuaded these women to visit the women's sharia court. Hence, women qazis and activists of the BMMA negotiated with male authority as they carved out a space to exercise their adjudicatory power in the plural legal system that governs Muslim law on marriage, divorce, and maintenance in India.

Based upon participant observation in the BMMA women's sharia court in Mumbai, this article explores the negotiations between male and female non-state actors in a legal pluralist framework of adjudication of Muslim personal law in India. It also conceptualizes gendered agency in these moments of negotiation. I identify three modes of collaborative contestation between male and female qazis: (1) everyday cooperation despite doctrinal differences; (2) the gradual assertion of female quasiadjudicatory power in and through everyday cooperation with male qazi; and (3) institutional competition interlaced with everyday cooperation. Building upon these ethnographic insights, this article makes three conceptual contributions to the scholarship on legal pluralism: First, I explore the modalities of interaction between non-state actors who exercise adjudicatory power within a framework of legal pluralism. Second, I draw attention to how gendered agency is constituted in a legal pluralist framework of adjudication of marriage and divorce. Third, I show how gendered agency

opinions and decisions rendered by these alternative dispute resolution forums are often admitted as proof. Gopika Solanki (2011) describes this as a system of shared adjudication where the state shares authority with non-state actors.

2. Pseudonyms have been used for all the names of qazis and women litigants as per anthropological convention. Given the intimate personal details of women's lives that were revealed in these interactions, using pseudonyms was deemed essential.

3. The mehr is the dower amount promised to the woman at the time of marriage. It is recognized in many schools of Islamic law. 
in a legal pluralist framework is forged at the intersection of individual agents, interactions, and institutions.

The first section of this article situates my research within the scholarship on legal pluralism in relation to non-state actors and gender. The second section outlines the article's methodology, and the third section lays out the wider context of legal pluralism in India and the emergence of women's sharia courts in the twenty-first century. The next three sections draw on my ethnographic fieldwork to map the modalities of negotiations between male and female qazis in sharia courts. The final section discusses how my ethnography contributes to our understanding of interactions between non-state actors and gender dynamics in legal pluralist systems.

\section{LEGAL PLURALISM: NON-STATE ACTORS AND GENDER}

\section{Non-state Actors and Legal Pluralism}

Studies of legal pluralism have explored a wide range of legal bases of non-state adjudicatory forums and their complex relationship with the state (Galanter 1981; Moore 1993; Randeria 2006; Sharafi 2014). The state, however, remains the pole around which debates on non-state law revolve. Even scholarship that questions the idealization of statist conceptions of the law does not tell us very much about the power dynamics between non-state actors who exercise adjudicatory power within a framework of legal pluralism (Solanki 2011; Redding 2014). Scholarship on legal pluralism, family law, and state power in other postcolonial contexts shows a similar preoccupation with the manifestation of state power (Peletz 2002, 2020; Agrama 2012; Hussin 2017). In Muslim-majority countries such as Egypt and Malaysia, the state has become more and more involved in the legal regulation and gradual institutionalization of Islamic courts adjudicating marriage, divorce, and maintenance payments of Muslims through the twentieth century (Peletz 2002, 2020; Agrama 2012; Hussin 2017).

Based upon fieldwork in Malaysia, Michael Peletz $(2020,14)$ remarks that the sharia courts play an important role in furthering the state's efforts to "define, codify, and normalise particular kinds of relations" and constitute "citizens as subjects." In an ethnography of personal status courts in Egypt, Hussein Agrama (2012, 75) shows how liberal conceptions of the public/private divide become firmly entrenched in the practice of personal status courts in Egypt as the family is conceptualized as a domain of "intimate, personal relations" in this space. The personal status courts in Egypt came into being with the absorption of the sharia courts into the national court systems, which led to increased state regulation of Islamic practice that was built upon a "definition of the essence of the sharia as concerned with 'family' matters" (99). A different logic of adjudication animates the legal pluralist framework within which Muslim personal law is administered in India. Since the state does not ostensibly recognize any of the alternative dispute resolution forums, such as the dar-ul-qaza, there is more room for interaction and competition between non-state actors. The Indian case, therefore, offers a vantage point for exploring the contours of interaction between nonstate actors who take on quasi-judicial roles. 


\section{Gender and Legal Pluralism}

Scholarship on legal pluralism and gender is broadly based on whether alternative dispute resolution forums contribute to feminist aims of gender justice (Nader 1993; Edwards 1997; Presser and Gaarder 2000; Basu 2012). Scholars have also explored the extent to which the appointment of women judges, especially in family courts, better serves the needs of women and children (Esposito 1982; Nurlealawati and Salim 2013; Mehdi 2017; Voorhoeve 2017). This debate has gained prominence in recent times with the appointment of Muslim judges in sharia courts adjudicating family law in several Muslim-majority countries such as Pakistan, Tunisia, Indonesia, and Malaysia (Jones 2019, 446). Ethnographic work on these courts shows that the appointment of female judges does not secure, in and of itself, gender justice for women. For instance, in Tunisia, female judges often have demanded extensive documentary evidence for granting divorce claims of women who alleged domestic violence, adulterous behavior by men, and non-payment of maintenance, but this emphasis on excessive documentation has not benefited women litigants (Voorhoeve 2017, 190). Female judges often have invoked gendered tropes of wifely duty and privileged marriage and family above work in adjudicating marital conflicts (190). In Indonesia, the adjudication of female judges, who have been serving in religious courts since the 1960s, has been shaped by extensive training on gender sensitivity conducted by women's organizations and local cultural and kinship practices (Nurlealawati and Salim 2013, 267).

This article furthers scholarship on legal pluralism by exploring the modalities of interaction between non-state actors in a legal pluralist domain. I further contribute to the scholarship on gender and legal pluralism by moving beyond questions of whether, how, and to what extent women's adjudication contributes to gender justice to critically explore the category of gendered agency itself in a legal pluralist context. Moving beyond any reified conceptions of women's interests, I delineate how women do gender and how we might conceptualize women's agency in moments when they negotiate male authority. This methodological move can be a promising tool for delineating the gradual transformation of gendered power dynamics as well as the entanglements of male and female quasi-adjudicatory power in a legal pluralist context. I build upon Saba Mahmood's (2005) critical conception of agency beyond the binaries of repression and resistance, and Barbara Risman's (2004) analysis of gender that is forged at the intersection of individuals, interactions, and institutions.

\section{METHODOLOGY}

This article is based on participant observation carried out over eleven months in a women's sharia court in Mumbai that is part of a network of such alternative dispute resolution forums run by the BMMA, an Islamic feminist movement in India. I studied its networks with two other male-run dar-ul-qazas (alternative dispute resolution forums run predominantly by male Islamic judges) in Mumbai, with which the female qazis of this court had frequent interactions with respect to cases. In the women's sharia adalat 
(court) established by the BMMA, only women can act as judges (qazis) (Jones 2019). ${ }^{4}$ I worked as an intern with the BMMA for eleven months. During this period, I observed the hearing of all cases in the women's sharia court. I interacted with the qazi and the litigants. Cases often overflowed the boundaries of the women's sharia court. Though the women's sharia court was part of the BMMA's larger project to counter male dominance in community adjudication forums, the female qazi in the court would often seek the endorsement of a male qazi in the neighborhood. Sometimes, she would refer cases of women who were unable to procure a divorce settlement from their husbands to the male qazi in the dar-ul-qaza of the AIMPLB. As an intern with the BMMA between October 2017 and September 2018, I helped in taking notes, filling out forms for litigants, and doing data entry for cases in the adalat. I attended hearings of all the cases (about 189, according to the BMMA's report that I helped to compile) that were filed during this period.

I accompanied the litigants as they travelled sometimes from the women's sharia court to the courts where male qazis held adjudicatory roles. I took field notes that tracked the interactions between the litigants, the adjudicatory strategies of the male and female qazis, and the ways in which they spoke about one another. Observations of these interactions provide access to the modalities of negotiations between the male and female qazis that are not recorded in the case registers of the women's sharia court. It is in these moments of interaction that we get a sense of how women judges negotiate male adjudicatory power, even while ostensibly challenging it. As per anthropological convention, pseudonyms have been used for all male and female qazis and litigants.

The women's sharia court was chosen since it represents a larger movement led by the BMMA to challenge male dominance in community adjudication forums that constitutes the legal pluralist domain of regulation of the Muslim family in India. A network of courts has emerged across India since 2013 where only women can adjudicate disputes of marriage, divorce, and maintenance in accordance with the tenets of the Quran and Muslim personal law (Jones 2019, 2020). Mumbai provides a useful site to explore this phenomenon since the city has been home to Muslim women's rights activist networks since the 1980s (Vatuk 2013, 349).

My positionality as a non-binary (biologically cis-gendered man) queer person has made me sympathetic to the struggles against gender inequality and gendered violence. As an intern who was working with the BMMA, I was perceived by the litigants as being part of the institution of the sharia court rather than being an outsider. The sharia court itself provided an enabling space of comfort for women where they could talk openly about the violence and injustice that they had faced in their families. In fact, the spatial logic of the sharia court blurred the boundaries between insider and outsider. My identity as a gender non-binary queer person made me acutely sympathetic to the

4. It is important to note here that neither the male nor the female qazis in India are officially recognized by the state, but the sharia courts run by them serve as important avenues for poor Muslim women seeking resolution of marital disputes. Their records are recognized and honored by litigants in Muslim neighborhoods. Women judges and activists more recently have been able to enforce their diktat using networks with local lawyers and the police. While the state does not recognize these alternative dispute resolution forums, the state courts routinely admit marriage and divorce certificates issued by these bodies as evidence in Muslim family law cases. Hence, the male and female qazis exercise and share adjudicatory power with the state (and with each other) in the adjudication of Muslim family law in India. 
everyday struggles against gender inequality. At the same time, I was also keenly aware of the complex ways in which gender struggles work within structures of power, and this awareness made me probe gendered agency in more depth through ongoing interactions in these courts.

Women were not perturbed by the presence of outsiders, including male relatives and clients. They were very open and candid about their experiences in this space. In my interactions with the litigants, I helped them fill out forms and understand legal documents that were written in English. I was asked by the head qazi to accompany these women to other sharia courts. This process helped me to build intimacy with my informants. Growing up to inadvertently internalize a lot of patriarchal judgments and gendered stereotypes about gay men, I was keenly aware of how even so-called projects of resistance to patriarchy are inscribed within networks of power, and this understanding prompted me to closely study and examine how men and women interact and how women's gendered agency is performed in these spaces.

\section{CONTEXT}

The last two decades of the twentieth century have witnessed several initiatives for a transnational advocacy of Muslim women's rights led by “educated cosmopolitan Muslim women" (Abu-Lughod 2013, 177). These initiatives build on local movements for gender equality led by Muslim women in Iran, Malaysia, Indonesia, Lebanon, and Egypt (177). In India during the late twentieth and twenty-first centuries, several Muslim women's rights networks based their struggles for gender equality on an understanding of the Quran (Vatuk 2013, 349; Tschalaer 2017, 56). The BMMA brought together some of these initiatives. It emerged as a concerted movement for gender equality in the Muslim family in 2007 (Niaz 2016, 30; Jones 2019, 450). The founders of the BMMA and its activists invoked transnational Islamic feminist ideals of gender equality and piety to enhance women's bargaining powers in matters of marriage, divorce, maintenance in the state as well as community adjudication forums (Vatuk 2013, 354; Tschaeler 2017, 71; Lemons 2019, 167).

The BMMA's activism for the reform of family law revolves around two major initiatives. First, activists of the BMMA have advocated for a draft bill that seeks further codification of Muslim personal law in India. This bill seeks the compulsory registration of marriages, provides for a minimum age of marriage at twenty-one, outlaws polygamy, and criminalizes oral, unilateral divorce by men. It includes irretrievable breakdown of marriage as a ground for divorce and advocates for a "Quranic method of divorce" that is informed by the principle of compassion and entails methods of arbitration (BMMA 2017, 16). Additionally, since 2013, the BMMA has also established sharia courts in several parts of India where only women can adjudicate disputes such as marriage, divorce, maintenance, and so on. This effort ostensibly serves to challenge the predominance of male judges in community adjudication forums or dar-ul-qazas. Women judges are trained by the BMMA to adjudicate disputes in the sharia court (16).

The sharia courts of the BMMA resemble the adjudication and functioning of a range of alternative dispute resolution forums in India that negotiate multiple actors in the state and civil society to address gender inequality in the family. However, the 
BMMA activists situate themselves squarely within an Islamic feminist ethical framework unlike these forums. Some of these women-run alternative dispute resolution forums include mahila adalats (the women's court) founded by the All-India Muslim Women's Personal Law Board (AIMWPLB) in Lucknow in 2005; the mahila shakti mandal (women's power circle) run by Women's Research Action, a non-governmental organization (NGO) in Mumbai; and the women's jamat (a community-based dispute resolution forum), modeled on male-run jamats in mosques founded in Pudukottai, Tamil Nadu, in 2003 (Vatuk 2013, 89).

The sharia courts share power with the state in the adjudication of Muslim family law (Solanki 2011, 41-45). Both the state and non-state adjudication forums can adjudicate marriage, divorce, and maintenance among Muslims. Statutory laws governing the Muslim family include the Dissolution of Muslim Marriages Act 1939, the Muslim Personal Law (Shariat Application) Act 1937, the Muslim Women's (Protection of Rights to Divorce) Act 1986, and the newly enacted controversial Muslim Women's (Protection of Rights on Marriage) Act 2019. Women can choose between alternative dispute resolution forums such as the sharia courts or state courts for getting a favorable divorce or maintenance settlement (Tschalaer 2017, 71; Jones 2019, 440). Neither the male nor the female qazi adjudicating Muslim personal law are formally recognized by the state in India. Yet their writ runs in neighborhoods where poor Muslim women routinely approach them for a favorable divorce or maintenance settlement. While the state does not accord formal recognition, state courts often admit marriage and divorce documents issued by these qazis as evidence in cases of Muslim personal law (Jones 2019, 440).

In the last three decades, the domain of Muslim personal law in India has witnessed the emergence of women's claims to religious and quasi-legal authority. Several groups, including Awaaz-e-Niswaan (Voices of Women), which was founded in 1987; the Women's Research and Action Group, founded in 1993; the Muslim Women's Rights Network, founded in 1999; the Muslim Women's Forum, founded in 2000; the AIMWPLB, founded in 2005, and the BMMA, which emerged in 2007, ostensibly challenge male dominance in the the everyday functioning of Muslim personal law (Jones 2020, 8). Several Muslim women's organizations, including the AIMWPLB and the Muslim Women's jamat have been involved in running women's sharia courts (Jones 2020, 23). The BMMA took the lead in the creation of a more systematic movement of women's sharia courts across India as it set up such courts in Mumbai, Pune, Ahmedabad, and Dindigul (23). Existing literature has explored the emergence of sharia courts as a challenge to male religious authority (Vatuk 2013; Tschalaer 2017; Jones 2020). In contrast, this article tracks the more complex, everyday negotiations between male and female judges in these courts.

5. Dissolution of Muslim Marriages Act 1939, https://www.indiacode.nic.in/handle/123456789/2404? locale =hi; Muslim Personal Law (Shariat Application) Act 1937, https:/www.indiacode.nic.in/handle/ $123456789 / 2303$ ? view_type $=$ search\&sam_handle $=123456789 / 1362 ;$ Muslim Women's (Protection of Rights to Divorce) Act 1986, https://legislative.gov.in/sites/default/files/A1986-25_1.pdf; Muslim Women's (Protection of Rights on Marriage) Act 2019, https://www.livelaw.in/pdf_upload/pdf_upload-362529.pdf. 


\section{NEGOTIATIONS}

In this section, I explore how Nasreen Shaikh, a female qazi of the BMMA who presides over a women's sharia court, shared adjudicatory power with Ibrahim, a male qazi in the same neighborhood. I found that the male and the female qazis cooperated in the adjudication of cases even while they disagreed about the interpretation of the Quran and the relationship between state law and Quranic injunctions-disagreements that became particularly pronounced during the recent national debate on the criminalization of triple talaq. ${ }^{6}$

Shaikh and Ibrahim were trained in very different ways of adjudicating Muslim personal law. Shaikh was trained as part of a concerted endeavor of the BMMA, begun in 2013, to train female qazi and thereby challenge male dominance in alternative dispute resolution forums. The curriculum of this training for female qazi consists of sections of the Quranic text that pertain to marriage, divorce, and maintenance rights of women; various aspects of legislation on Muslim personal law, including Muslim Women's (Protection of Rights on Divorce) Act 1986 and the Dissolution of Muslim Marriages Act 1939. Female qazis are also trained in secular statutes that deal with women's rights in India such as the Protection of Women from Domestic Violence Act 2005. ${ }^{7}$ This training is conducted in workshops spread over the year; it primarily caters to working-class Muslim women who have been active in their neighborhoods as members of various alternative dispute resolution forums. ${ }^{8}$ The initiative can be situated within the intellectual tradition of Islamic feminism in India that focuses on the Quran as the primary text for guidance on moral, ethical norms, and legal matters and eschews certain misogynist interpretations of the hadith as accretions. ${ }^{9}$ Additionally, Shaikh was part of an activist tradition of alternative dispute resolution in Mumbai, whereby women negotiated with state and non-state actors to resolve women's marital disputes. ${ }^{10}$

6. Triple talaq is a form of oral, unilateral divorce practiced in India, whereby the utterance of the word "talaq" three times leads to the wife being divorced by the husband. This practice is recognized in the Hanafi tradition of Sunni Islam. In recent times, a great deal of women's mobilization around Muslim personal law is premised on the legality of this method of divorce. On August 27, 2017, the Supreme Court of India declared the practice of oral, unilateral divorce unconstitutional. Most Muslim women's groups welcomed the judgment. The Union government led by the right-wing Bharatiya Janata Party subsequently proposed to criminalize oral, unilateral divorce. This proposal witnessed a chasm between women's groups and civil society actors who claimed to represent Muslim women. Some of them opposed the move as they felt that it was meant to target Muslim minorities, whereas some women's groups felt that the law would act as a necessary deterrent to stop the practice of oral, unilateral divorce. The Bharatiya Muslim Mahila Andolan (BMMA), along with the All-India Muslim Women's Personal Law Board supported the legislation. For a detailed account of the debates around Muslim women's movements against oral, unilateral divorce, see Punwani 2016. For the mixed responses to the proposal to criminalize triple talaq, see Punwani 2018. In the face of much opposition in Parliament, the proposal was finally enacted into law on July 25, 2019. The Muslim Women's (Protection of Rights on Marriage Bill) 2019 made the pronouncement of triple talaq a cognizable offence, which would ensure a penalty of up to three years of imprisonment with a fine.

7. Protection of Women from Domestic Violence Act 2005, https:/legislative.gov.in/sites/default/files/ A2005-43.pdf.

8. Interview with Noorjehan Safia Niaz, founding member of the BMMA, Mumbai, October 10, 2017.

9. For more details on the background of this Islamic feminist method of interpretation of the Quran, see Wadud 1999, 2015. Amina Wadud's work is focused on recovering the Quranic text to challenge the androcentrism of existing paradigms of Quranic interpretation; she also proposes a reading of the Quran that emphasizes women's agency in the creation of a just social order. The hadiths are sayings of the Prophet.

10. Interview, Mumbai, November 13, 2017. 
In contrast, Ibrahim was trained as a qazi at the Dar-ul-uloom Deoband, a prominent seminary in the Saharanpur district in Uttar Pradesh. The curriculum consisted of the Quran and several hadith collections. ${ }^{11}$ Several dar-ul-qazas function across India, which have been established by the AIMPLB. ${ }^{12}$ Ibrahim worked within the figh tradition, a tradition guided by Islamic legal principles drawing upon human interpretations of the moral, ethical normative standard of sharia. ${ }^{13}$ This tradition of interpretation is focused upon formulating legal principles based on the Quran and the hadith. The pronouncements of the qazis are not based upon formal legal authority but, rather, on their religious credentials.

Both male and female qazis try to lay claim to religious and quasi-adjudicatory authority, albeit in different ways. Shaikh emphasized the significance of the Quran, while Ibrahim underlined the limitations of reliance only on the Quran. Additionally, Shaikh invoked recent developments in state law while addressing marital disputes such as triple talaq, while Ibrahim and the other qazis of the AIMPLB expressed their dislike for women being able to approach the courts as well as for state intervention in marriage laws. The difference in their attitudes demonstrates the different ways in which the BMMA and organizations such as the AIMPLB understood the role of the state and religion in adjudicating Muslim personal law in India. The female qazis of the BMMA brought together an emphasis on moral, ethical conduct based upon the Quran and a willingness to invoke state law for women's interests. Such efforts function as part of the intellectual universe of the BMMA, shaped by transnational Islamic feminist discourse and its negotiation with concerted local struggles for gender equality vis-à-vis state and non-state actors in India. In contrast, the male-run dar-ul-qazas have traditionally attempted to carve out a space outside the domain of state law for the resolution of Muslim marital disputes, which explains their discomfort with state intervention.

Notwithstanding the difference in training of Shaikh, Ibrahim, and the other qazis of the AIMPLB, they function within the legal plural system of adjudication of Muslim personal law in India. ${ }^{14}$ The proliferation of various forms of male and female authority in this legal landscape also leads to various interactions between them. In adjudicating cases of divorce, Shaikh frequently cited the Ayats of the Quran as she invoked virtues

11. Interview, Mumbai, September 10, 2017.

12. As the qualification of male qazis is not defined by law, they hail from a range of backgrounds and function within a variety of institutional settings. Some male qazi are attached to a mosque or a charitable institution, while others have their own office and double as practicing lawyers (Solanki 2011, 276). Ibrahim worked in an independent office close to a family court, while the other qazis discussed in this article were part of the dar-ul-qaza run by the All-India Muslim Personal Law Board in Mumbai (AIMPLB). This forum was situated in the basement of a mosque. The AIMPLB was founded in 1972 by Muhammad Tayib, a director of the renowned seminary at Deoband as a congregation of ulama (religious scholars). The central aims of the AIMPLB are the preservation of the current legal structure governing Muslim personal law and opposition to any state encroachment on the same. For more details on AIMPLB, see Jones 2010.

13. Sharia can be defined as the moral, ethical ideal that constitutes the domain of Islamic law. Wael Hallaq $(2012,11)$ defines the sharia as the "hermeneutical, conceptual, theoretical, practical, educational, institutional system" that constitutes a project of discovering God's moral will. For a detailed historical analysis of sharia, see Hallaq 2009, 2012. The figh tradition builds upon judgments of particular jurists in Islamic jurisprudence based upon their understanding of the Quran and hadith.

14. In fact, the Supreme Court of India in the landmark judgment Vishwa Lochan Madan v. Union of India refused to entertain a plea to declare all sharia courts illegal and emphasized the significant role that they play in providing accessible alternative dispute resolution. Vishwa Lochan Madan v. Union of India, 2014 S.C. 2957. 
of compassion (raham), equality (barabari), and justice (insaf). ${ }^{15}$ Shaikh was unequivocal in her condemnation and disapproval of misogynist modes of divorce such as oral, unilateral divorce that she thought were not in keeping with the tenets of the Quran. She was in favor of state legislation to outlaw these actions. She frequently cited the Ayats of Surah Nisa to argue for compassion and propriety in the event of divorce and breakdown of marital relationships. She repudiated triple talaq by summing up sections of the Quranic verse Surah Talaq: "Tum aurat ko jab chorte ho toh izzat ke saath choro us ka jo bhi hai usko de do" (when you divorce women, treat them with dignity and give them whatever is due to them). ${ }^{16}$

Shaikh rejected the method of oral, unilateral divorce as not being in keeping with the principle of compassion underlined in the Quranic verses that she read, and she frequently repudiated male litigants who had indulged in this practice. She also invoked the impending legislation on triple talaq to chastise litigants. At the same time, Shaikh considered the sacredness of the Quran itself as infallible and was critical of secular Muslim women's groups that did not respect the Quran. She expressed her disapproval of such groups on several occasions during my fieldwork. On one occasion, she said: "Jo Quran ko leke baat nahi kar na chahta us ke saath hum baat nahi kar naa chahte" (we [qazi and the BMMA] do not want to talk to anyone who does not respect the Quran or engage it). ${ }^{17}$

While Shaikh asserted her adjudicatory power in the neighborhood as a female qazi, she also depended on Ibrahim, a male qazi who presided over his own dar-ul-qaza in the same neighborhood in Mumbai, to endorse her decisions. Litigants who visited Shaikh's court were often sent to Ibrahim's court. He would then issue a talaq nama to the litigants. Ibrahim endorsed Shaikh's judgments, but he voiced a different conception of the relationship between the Quran, cultural practices, and state law. Ibrahim emphasized the importance of compassion as an important Quranic principle

15. The various forms of divorce that were common in this court were: (1) khula: a form of divorce initiated by the wife where the presence of the husband is necessary, the husband grants the divorce, but the wife is usually expected to return the mahr (dower) and other gifts given to her by her husband as well as to forego maintenance claims - this gesture by the wife is a form of compensation to the husband for the divorce; (2) faskh-e-nikah: a form of divorce initiated by the wife that can be decreed by a qazi in the absence of the husband - the wife is not required to return her dower or any other wedding gifts acquired during her marriage; (3) talaq-e-mubarat (divorce by mutual consent); and (4) talaq-e-ehsan: a form of divorce where a husband pronounces divorce over a period of three months. Reconciliation is possible until the third declaration of divorce. For a more detailed discussion, see Lemons 2017, 2019.

16. Field notes, January 11, 2018. This observation is based upon a verse in Surah Al-Talaq (65:1, 65:2), which mandates the husband to part ways with the wife in a dignified fashion. This verse was extrapolated from booklets containing translations of some Quranic verses circulated by members of the BMMA. The English translation of this verse reads as follows: "O you prophet, if any of you have divorced the women, then they should be divorced while ensuring that their required interim is fulfilled and keep count of the interim. You shall reverence God your Lord, and do not evict the women from their homes, nor should they leave, unless they have committed a proven adultery. These are God's limits. Anyone who transgresses God's limits has wronged his person. You never know; perhaps God will make something come out of this" (BMMA 2015, 13). "Then, once the interim is fulfilled, either you remain together equitably, or part ways in a just manner and have it witnessed by two just people from among you; This is to enlighten those who acknowledge God and the Last day. Whosoever reveres God, He will look out for him” (13). The BMMA's Urdu and Hindi translations draw from an English translation of the Quran by Yuksel, Saleh, and Schulte-Nafeh 2007. These verses are often cited by activists of the BMMA to mobilize support against triple talaq.

17. Field notes, Mumbai, November 27, 2017. 
and mandated talaq-e-ehsan, a form of talaq (divorce). ${ }^{18}$ Yet Ibrahim was more ambiguous about the criminality of triple talaq and the prospect of enhanced state intervention in Muslim personal law. In his interactions with clients, he always expressed his disapproval of clients, especially women, approaching the state and the state courts and insisted that the best way for Muslim families to resolve their marital disputes was by approaching dar-ul-qazas and qazis in their neighborhoods. ${ }^{19}$ In an interview, he clarified his conception of the authority of the Quran:

Quran is like a headline of a newspaper. It does not tell you everything. There are many practices that may not be found in the Quran. One must read the hadith (Prophet's sayings) collections to understand the message of the Quran. There are many practices that you will discover in the lifetime of the Prophet's companions (sahaba). Knowledge of religiosity (deen) is like a sea. There is a beginning but there is no end to it. It is impossible for a human being to know the whole world (duniya). Similarly, a human being cannot acquire knowledge of the whole of deen. No human being can assert that they have complete knowledge of all deen. But that doesn't mean that we shouldn't try. ${ }^{20}$

Ibrahim's formulation of piety was different than Shaikh's. He outlined the difficulty of grasping the knowledge of faith in its entirety as well as the difficulty of finding ready-made prescriptions of conduct in the Quran. He was therefore skeptical of state intervention to impose the tenets of the Quran. In contrast, Shaikh regularly referred to the newly proposed criminal laws as well as to the Quranic principles to repudiate some modes of divorce practiced by Muslim men. Though Shaikh and Ibrahim espoused competing normative conceptions of the relationship between the Quran and the state, Ibrahim endorsed her decisions. He issued documents recording the details of the divorce to couples that were referred to him by Shaikh.

The shared adjudication between Shaikh and Ibrahim can be traced more closely by following the itineraries of a case that traversed their courts. In a case registered with the women's sharia court, Asifa, a twenty-year-old Muslim woman claimed that she had been divorced by her husband using the method of oral, unilateral divorce. ${ }^{21}$ According to the petition, Asifa's husband Amir had arbitrarily divorced her by pronouncing talaq three times while she was staying at her mother's place. In the petition, she said that she did not want to stay with her husband and requested that he provide post-divorce maintenance for her and her child. On hearing about Asifa's case, Shaikh reprimanded her husband for pronouncing an oral, unilateral divorce. She laid out the proper procedure of the divorce that he should have followed according to the tenets of the

18. Talaq-e-ehsan is a form of divorce where the pronouncement of talaq by the husband is spread over three months, and a reconciliation is possible before the pronouncement of the third and final divorce. This method of divorce allows the spouses to think about the possibility of reconciliation and is usually spread over three months in contrast to the oral, unilateral pronouncement of divorce by men that instantaneously ends a marriage.

19. Field notes, Mumbai, December 19, 2017; Interview with Ibrahim, Mumbai, September 10, 2018.

20. Interview with Ibrahim, Mumbai, September 10, 2018.

21. Case no. 166, BMMA Case Register (2017-18). 
Quran. She also warned him of a "new law" that had come into place that would invite a prison term if the man were to pronounce triple talaq. ${ }^{22}$

At the time of the filing of this case, the law was still a proposal. During the hearing of this case in the sharia adalat, Imran's father mentioned that this kind of divorce (triple talaq) was permissible in "Muslim law," to which Shaikh promptly retorted: "To hell with Muslim law (Muslim law gayi dabbe mei). According to the new law, there is a three-year prison term for anyone pronouncing a triple talaq." Shaikh not only pronounced the couple divorced but also insisted that the husband pay a lump sum as a post-divorce maintenance payment as well as pay for the child. Once she arrived at a decision, she sent the couple to Ibrahim qazi to finalize the divorce on these terms. Asifa decided that she did not want maintenance for the child but wanted complete custody. The terms of the divorce were altered accordingly by Ibrahim when the divorce papers were finalized.

Ibrahim qazi did not challenge the terms of the divorce agreed upon by the couple in Shaikh's court. But he was ambiguous about the new proposed law on oral, unilateral divorce. While drafting the divorce papers, he spoke of the new law. ${ }^{23}$ Ibrahim did not approve of oral, unilateral divorce, but he did not endorse the new law. He said that there were times when a man was compelled to act in haste and pronounce a divorce, but the practice was not ideal. The divorce papers mentioned that the man had divorced his wife following the method of talaq-e-bain in the presence of witnesses. ${ }^{24}$ The sudden occurrence of the event of triple talaq was overlooked; the divorce was said to have occurred because of the inability of the couple to attempt a reconciliation (na-ittefaki). The post-divorce maintenance amount and the amount of mehr was specified, and it was agreed by both parties that the amount would be paid to the woman at the woman's sharia court. The woman was given custody of the child for her entire life. Her husband would have no custody rights, but he would not have to pay for the child. Ibrahim qazi added a clause in the talaq nama stating that the couple had agreed to these terms and that the woman would not approach any court or the police or an $\mathrm{NGO}$ to claim maintenance for her child. In his interaction with the litigants, Ibrahim expressed his dislike of Muslim women approaching the state courts and formal state institutions for a divorce.

As highlighted earlier, he asserted in an interview that Muslims should try to get their domestic disputes resolved through dar-ul-qazas (neighborhood councils) instead of approaching the state court. The ethnographic observations in this section enable us to explore the modalities of negotiation between non-state actors-Shaikh and Ibrahim qazi, in this instance-who share quasi-adjudicatory powers within a framework of legal pluralism. In the above sections, I have shown that the adjudication of the qazis is shaped by everyday cooperation, even while they hold contradictory views about the Quran and its relationship to state law. The ethnographic vignette provides a lens

22. Field notes, Mumbai, December 19, 2017.

23. The male qazi felt the need to comment upon this new legislation without myself or any of the litigants bringing it up. This shows how he was both aware of, and responding to, recent moves by the state to legislate triple talaq. Even while he functioned within the fiqh tradition, he could not ignore the recent developments in state law as well as the gradual assertion of women qazis in the domain of adjudication of Muslim personal law.

24. Reference no. 20324/ 2018, Talaq-e-Mubarat Papers, January 27, 2018. 
for exploring women's agency in these forums. Shaikh's adjudication was not a straightforward challenge to male dominance in alternative dispute resolution forums. It was rooted in particular ways of conceptualizing the principles of the Quran and their relationship to state law.

It is useful here to draw on Saba Mahmood's (2005) approach to agency beyond the binaries of resistance and repression and as residing in particular ways of inhabiting authority. In this instance, Shaikh's negotiation with male adjudication was mediated by particular ways of understanding and inhabiting the authority of the Quran. Shaikh and Ibrahim differed in their interpretation of the Quran and in their understanding of how it should relate to state law. They held contradictory views on the best way to understand a moral, authoritative tradition - in this instance, the correct way of living an ethical life in accordance with the principles of the Quran. At the same time, they carved out a space of everyday cooperation as Ibrahim endorsed divorces that were overseen by Shaikh. This dispute between Shaikh and Ibrahim is part of a larger debate between Islamic feminist activists and traditional male authorities who administer Muslim personal law in India (Vatuk 2013, 359). Islamic feminist activists have argued that the accretion of misogynistic interpretations of the hadith and the fiqh have shaped the patriarchal practice of Islamic law; hence, these interpretations must be rejected in favor of the central ethical message of the Quran (Bauer 2015, 167; Mir-Hosseini 2015, 28). On the other hand, the male-run dar-ul-qazas in India are trained in the fiqh tradition (Lemons 2019, 616). This training shapes their views on the salience of the fiqh tradition in the adjudication of Muslim law.

\section{GRADUAL ASSERTION}

As I have shown in the earlier sections, Shaikh would often send her clients to the male qazi to get him to endorse the terms of divorce arrived at in her court. A couple of months into my fieldwork, Shaikh gradually became more assertive about her identity as a female qazi, and her everyday cooperation with Ibrahim was interlaced with increased assertions of her adjudicatory power. Even as she continued to send clients to the qazi for issuance of talaq nama, Shaikh emphatically told litigants that they must not alter the terms of the divorce when they approached the male qazi. ${ }^{25}$ The role of the male qazi, she often asserted, was to merely endorse her decision. At times, there was a lot of confusion as litigants disagreed about the terms of the divorce when they approached the male qazi. This coincided with the increasing popularity of the sharia courts of the BMMA as well as a gradual expansion of its networks with other state and non-state actors such as civil society activists, the police, and lawyers both in other Muslim neighborhoods in Mumbai and in other parts of the country. Throughout the backdrop of these heated debates on Muslim personal law reform in the public domain, the activists of the BMMA became prominent voices representing Muslim women in public discourse. Consequently, Shaikh began to issue a document with the details of the terms of divorce such as the amount of post-divorce maintenance, the quantum of mehr, and

25. This development became apparent a couple of months into my fieldwork in December 2018. 
the custody of children when she sent her clients to the male qazi. She also started issuing her own talaq nama to some clients.

In this vignette, we can see yet another aspect of the interactions between Shaikh and Ibrahim. Shaikh's agency was shaped gradually in and through a mode of everyday collaboration with the male qazi. We can conceptualize her agency as being forged in a legal domain shot through with certain cultural expectations about interactions between men and women and gendered institutional logics of alternative dispute resolution forums. Shaikh inhabits an arena of alternative dispute resolution that has been traditionally dominated by men, which mediates the modalities of her interaction with the male qazi. But she was also seeking to gradually transform the gendered institutional logics of this arena in and through these moments of collaborative contestation. We can see this in her gradual assertion of her agency as a qazi, her assertion to her clients about the remit of the male qazi in only endorsing decisions agreed upon in her court, and then her issuing her own talaq nama.

\section{INSTITUTIONAL COMPETITION, EVERYDAY COOPERATION, AND OVERLAPPING JURISDICTIONS}

In this section, I delineate the relationship between Shaikh and a male qazi in a dar-ul-qaza of the AIMPLB. There are several such dar-ul-qazas of the AIMPLB spread across India (Vatuk 2013; Jones 2019, 2020). At an institutional level, the AIMPLB and the BMMA have been at loggerheads over the question of Muslim personal law reform and especially over the remit and adjudicatory power of female qazis. The AIMPLB has opposed women's claims to the office of the qazi (Vatuk 2013). In the backdrop of the debate over triple talaq, the animosity between the AIMPLB and the BMMA has been particularly pronounced in the public sphere of debate on Muslim personal law. The present-day Bharatiya Janata Party government's proposal to enact criminal legislation to outlaw the practice of oral, unilateral divorce has found the BMMA and the AIMPLB in opposing camps (Jones 2020). While the BMMA members have held several press conferences and demonstrations to support this legislation, the AIMPLB has publicly opposed the legislation, terming it an act of state interference with Muslim personal law and sharia (Punwani 2016, 2018). The AIMPLB has always expressed its vehement opposition to Muslim women's groups taking over the adjudication of Muslim personal law, especially with regard to the office of the qazi (Vatuk 2013; Jones 2019, 2020).

However, in the adjudication of the women's sharia court run by the BMMA, one encounters a more layered narrative. Even as the BMMA and the AIMPLB fight over the question of female claims to the office of the qazi and state intervention in Muslim personal law in the public sphere, the adjudication of cases in the women's sharia court has increased, based on acts of everyday cooperation interlaced with the gradual assertion of female adjudicatory power by women qazis. In instances where men have deserted their wives or where men have refused to appear before the women's sharia court, Shaikh would refer her clients to the dar-ul-qaza of the AIMPLB and recommend that they apply for a faksh-e-nikah. This is a form of divorce that is available to women ex-parte when their husbands are absent or when their husbands have deserted them. 
I have accompanied some women to the dar-ul-qaza of the AIMPLB when they have sought such divorces.

In these instances, the male qazi would usually be sympathetic to the women who have been referred to the dar-ul-qaza by Shaikh. The male qazi would not explicitly acknowledge the adjudicatory power and office that Shaikh held as a female qazi, but he would help the women that she had referred to him. When Shaikh approached the court, the male qazi referred to her by her first name rather than as a qazi. While the AIMPLB and the BMMA competed in the public sphere of debate on Muslim personal law, there was overlap between their jurisdictions in the functioning of sharia courts. I will trace the modalities of this negotiation by building on the itineraries of a case that travelled from the women's sharia court of the BMMA to the male dar-ul-qaza of the AIMPLB.

Saima, a thirty-five-year-old woman, requested a divorce (khula) from the women's sharia court of the BMMA in December 2017, complaining of routine domestic violence at home. ${ }^{26}$ When her husband did not cooperate with her and refused to appear at the court, Shaikh, the female qazi, advised her to approach the male dar-ul-qaza and obtain a faksh-e-nikah. Two women members of the BMMA and I accompanied Saima on her trip to the dar-ul-qaza of the AIMPLB. ${ }^{27}$ The male qazi was sympathetic with Saima's plea for a divorce. He asked her to fill out a form that would contain the details of her case, including the fact that she had already been living separately from her husband for fourteen years. ${ }^{28}$ The BMMA members implored the qazi to find a solution to Saima's problem, and the male qazi said that he would put out an advertisement in the newspapers enquiring about the whereabouts of the husband and that, if no one responded, he would issue a talaq nama as requested by Saima. He also enquired about the well-being of Shaikh. In the interactions with the male qazi, the BMMA members did not refer to Shaikh as a "qazi" or to the BMMA's sharia court as such. They referred to the women's sharia court as a "mahila mandal" (women's organization). ${ }^{29}$ The male qazi also referred to the BMMA's women's sharia court as a mahila mandal. The contentious issue of the adjudicatory power and appointment of women qazis, which framed the fierce contestation between the BMMA and the AIMPLB, did not come up in these interactions.

While this thorny issue of the authority of female qazis was avoided in conversations between activists of the BMMA and the male qazi, the regular traffic of cases between the women's sharia court and the male dar-ul-qaza continued. Women activists of the BMMA referred cases that they could not resolve to the dar-ul-qaza of the AIMPLB. In their visits to the dar-ul-qaza, they met women who were unhappy with the outcome of their cases adjudicated by the AIMPLB qazi. Women activists of the BMMA would then urge these women to visit the sharia court run by the BMMA. On one particular occasion, while waiting for our turn in the dar-ul-qaza, we met Afza, another woman who was aggrieved because of domestic violence and was seeking a divorce from her husband. Afza was visibly disturbed. We asked her about the details

26. Case no. 19, BMMA Case Register, 2018.

27. Field notes, Mumbai, February 20, 2018.

28. Field notes, Mumbai, February 20, 2018.

29. Field notes, Mumbai, February 20, 2018. 
of her case. She said that she had been abused by her husband and her in-laws and that she had been staying with her mother for some time. She had filed for a divorce from her husband at the dar-ul-qaza, but the husband had never appeared at the hearings. ${ }^{30}$ The members of the BMMA's sharia court advised her to approach the women's sharia court of the BMMA. At the same time, they requested the male qazi at the dar-ul-qaza to pay special attention to her case.

A few weeks later, Afza turned up at the women's sharia court of the BMMA. ${ }^{31}$ She explained that her husband had been sent a notice several times and that, if he still did not turn up, the members of the women's sharia court were going to approach the police. Shaikh critiqued the dar-ul-qaza of the AIMPLB for not handling the case properly and suggested that they must have advised the husband to not turn up. In this court, Shaikh assured her: "We not only work to get women maintenance (from the husband), but we are attendant to her difficulties (taqleef)." 32 One of Shaikh's colleagues said that the women's sharia court was not just a court but also a woman's sharia adalat. As the case proceeded, the husband did eventually appear at the court. It is clear from this ethnographic vignette that the woman qazi sought the male qazi's support to help Saima procure a divorce from her absconding husband. In the interactions between the members of the BMMA, we see this ethic of cooperation. These negotiations play out even though the BMMA and AIMPLB are locked in a fierce debate about Muslim personal law reform and the legitimacy of the office of female qazis.

One can trace the complex way in which the gendered agency of the female qazi is shaped in this instance at the intersection of individual agency, interactions between male and female qazi, and institutions. Shaikh is an active member in the efforts of the BMMA to challenge male dominance in alternative dispute resolution forums at an institutional level. But, at the same time, she is seeking to forge networks with male qazis to get favorable divorces for women who approach her court. In moments of interaction with the male sharia court, new alliances are being forged with women who feel betrayed by the male-run courts. As we see in Afza's case, the members of the BMMA persuaded her to approach a women's sharia court when her case did not get resolved by the male dar-ul-qaza. Hence, everyday cooperation is laced with efforts to carve out a space for adjudication in the women's sharia court.

\section{NON-STATE ACTORS, GENDER, AND LEGAL PLURALISM}

These vignettes illuminate the modalities of interaction between a male qazi and a female qazi who share quasi-adjudicatory power in the plural legal system of administration of Muslim personal law in India. The male and female qazis inhabit an ethic of cooperation in adjudicating disputes of marriage, divorce, and maintenance, even while they demonstrate distinct normative conceptions about Quranic interpretation and its relationship to state law. In presenting a fine-grained analysis of these interactions between non-state actors, this article expands the domain of enquiry in legal pluralism beyond existing scholarship on the relationship between the state

30. Field notes, Mumbai, February 20, 2018.

31. Field notes, Mumbai, February 26, 2018.

32. Field notes, Mumbai, February 26, 2018. 
and non-state adjudicatory forums (Galanter 1981; Moore 1993; Randeria 2006; Sharafi 2014) and the gradual institutionalization of family law adjudication forums through an expansion of state power (Peletz 2003, 2020; Agrama 2012; Hussin 2017). In contrast to the narrative of institutionalization of family law adjudication forums in Muslimmajority contexts in parts of the Middle East and South East Asia, the Indian case provides us with an opportunity to expand socio-legal exploration into how non-state actors interact and share power. This Indian example, which showcases a comparative perspective, provides a sense of the conceptual possibilities of legal pluralism and what it might look like if we shift our focus away from a narrative of state centralization and toward networks of power that shape individual actors within a legal pluralist framework.

This article further explores women's agency in these moments of negotiation and expands the domain of inquiry into gender and legal pluralism beyond questions of whether and to what extent alternative dispute resolution forums contribute to gender justice (Nader 1993; Edwards 1997; Presser and Gaarder 2000; Basu 2012) and if women's inclusion as female judges in family law courts serves the interests of women and children (Esposito 1982; Nurlealawati and Salim 2013; Voorhoeve 2014; Mehdi 2017). ${ }^{33}$ It is useful to consider Saba Mahmood's (2005) critical theory of agency beyond repression and resistance. Based on her exploration of women participants in a mosque movement that was part of the Islamic revival in twentieth-century Egypt, Mahmood argues for conceptualizing agency beyond the binaries of repression and resistance to focus on the "multiple ways in which women inhabit norms" (15). Mahmood critiques liberal feminist notions of agency that are understood as autonomy and resistance to structures of domination (8). She builds on her enmeshment with the lives of women participants of the mosque movement who taught and learned Islamic scriptures in particular ways and cultivated bodily dispositions such as modesty and femininity (22). Her intervention has had a profound effect in reconceptualizing notions of women's agency beyond autonomy, subordination, and resistance (Madhok, Phillips, Wilson 2013; Phillips 2015.

Though Mahmood's (2005) theorizing is based on the lives of women who do not quite participate in the structures of the state and legal institutions, her notion of agency offers a valuable resource for understanding women's adjudication and negotiation with legal pluralism. The agency of the female qazi can be conceptualized by paying attention to the ways in which she inhabits a moral, ethical tradition and negotiates with male judges. These moments of negotiation cannot be reduced to mere acts of resistance or subordination vis-à-vis male adjudicatory power. Shaikh's gendered agency as a qazi, therefore, was not a mere challenge to the authority of the male qazi. Her actions as a female qazi were shaped by her ideas about particular ways of inhabiting the moral,

33. A similar line of enquiry is pursued by some scholarship that explores the relationship between religion and gender equality in particular institutional contexts. For example, Eman Abdelhadi $(2017,11)$ in her exploration of employment opportunities for American Muslim women finds that women's mosque participation enhances their engagement with civic life and work force participation. Her work charts the indeterminate relationship between markers of religiosity and employment status of American Muslim women, thereby belying any claims of religiosity undermining gender equality and women's employment. This scholarship dwells broadly on what causes or inhibits women's participation and gender equality in the workforce. 
ethical tradition of the Quran and its relationship to state law. At the same time, she was engaged in an ethic of everyday cooperation with the male qazi in her neighborhood where she consolidated her adjudicatory power as a female qazi gradually in and through everyday cooperation with him.

A critical theory of gendered agency provides a useful lens for understanding how gender is negotiated in moments of collaborative contestation between non-state actors. My exploration of gendered agency in the domain of legal pluralism mirrors recent scholarship on the ways in which gender is negotiated by female judges in state courts (Mehdi 2017) and in the legal profession at large (Ballakrishnen 2019). In her ethnographic work on elite law firms in India, Swethaa Ballakrishnen notes how a modicum of gender agnosticism in these firms was an outcome of their zeal to emulate "modern" and "meritocratic" Western law firms without an explicit commitment to gender equality (128). A non-discriminatory approach to gender was achieved in these spaces almost by accident or, as one of Ballakrishnen's informants put it, "sometimes not consciously ... it just happened that way" (129). Similarly, Rubya Mehdi (2017, 224), in her study of female judges in Pakistan, notes how women judges face the challenge of "doing justice" in a manly way as they inhabit a male-dominated environment. Women judges often "de-emphasize" their femininity by "wearing minimal colour, make-up or jewels" and dressing in "simple clothes" that they take to be a marker of gender neutrality (227). Building on this scholarship, I have attempted an analysis of the category of gendered agency itself and have shown how it is constituted by networks of power and everyday negotiations with male authority.

It is helpful to conceptualize gendered agency in a legal pluralist domain as being shaped at the intersection of individual agency, interactions between men and women, and institutions. It is useful here to draw on Risman's (2004) conception of gender as social structure. Risman argues that gender as social structure creates different opportunities and constraints for the sexes at three different levels: (1) at an individual level where gender as social structure shapes the production of gendered selves; (2) during interactions between men and women as these are mediated by cultural expectations even when men and women occupy "identical structural positions"; and (3) institutional domains that are shaped by gender-specific regulations (433). The ethnographic evidence presented in this article shows the dynamic ways in which gendered agency works at these levels in a legal pluralist framework. At the individual level, Shaikh has carved out a space for herself as a woman qazi. But this only happens in and through her inhabiting an ethic of everyday cooperation with the male qazi. This gender dynamic needs to be understood within the context of conventional male dominance in alternative dispute resolution forums that administer Muslim personal law in India. Hence, women qazis do not always directly confront male qazis but, rather, gradually assert their adjudicatory power during moments of everyday cooperation with male qazis. Even when women seek to challenge male authority, their gendered agency is shaped partially by existing norms of interaction between male and female qazis.

In the adjudication of cases, women qazis are not able to completely overcome the power asymmetry between the AIMPLB and the BMMA. Women activists have attempted to counter the dominance of the AIMPLB in the administration of Muslim personal law at an institutional level. At the same time, in everyday negotiations that constitute the domain of Muslim personal law, the BMMA activists routinely 
seek the help of the qazis of the AIMPLB to get favorable pronouncements for women in cases where their authority falls short. But, even while doing so, they attempt to attract aggrieved women who are dissatisfied with the functioning of the AIMPLB to their fold, which shows how women negotiate, inhabit, and transform gender at an individual and institutional level.

\section{CONCLUSION}

An ethnographic exploration of non-state actors adjudicating Muslim personal law in India enriches our conceptions of the practice of legal pluralism beyond the state. While state power remains pervasive in regulating the family and family law in jurisdictions in Muslim-majority countries in the Middle East and South-East Asia, the legal domain in India shows how the power and authority of non-state actors shapes the practice of legal pluralism. Shifting focus away from state power also helps us to better appreciate the myriad ways in which women inhabit and transform gender norms at an institutional and individual level in their negotiations with non-state actors and institutions that constitute a plural legal domain.

\section{REFERENCES}

Abu-Lughod, Lila. 2013. Do Muslim Women Need Saving? Cambridge, MA: Harvard University Press. Abdelhadi, Eman. 2017. "Religiosity and Muslim Women's Employment in the United States." Socius: Sociological Research for a Dynamic World 3: 1-17.

Agrama, Hussein Ali. 2012. Questioning Secularism: Islam, Sovereignty, and the Rule of Law in Modern Egypt. Chicago: University of Chicago Press.

Bauer, Karen. 2015. Gender Hierarchy in the Qur'ān: Medieval Interpretations, Modern Responses. Cambridge, UK: Cambridge University Press.

Ballakrishnen, Swethaa S. 2019. "Just Like Global Firms: Unintended Gender Parity and Speculative Isomorphism in India's Elite Professions." Law $\mathcal{G}$ Society Review 53, no. 1: 108-40.

Basu, Srimati. 2012. "Judges of Normality: Mediating Marriage in the Family Courts of Kolkata, India." Signs: Journal of Women in Culture and Society 37, no. 2: 469-92.

BMMA (Bharatiya Muslim Mahila Andolan). 2015. Quran Dwara Surakshit Aur Protsahit Kiye Giye Muslim Mahilao Ke Qanooni Huq [Muslim women's legal rights protected and promoted by the Quran]. Belgaum: Omega Publications.

2017. Muslim Family Law, 2017: Draft for the Bill. Belgaum: Omega Publications.

Edwards, Patricia E. 1997. "Gender Issues in Family Law: A Feminist Perspective." Family Court Review 35, no. 4: 425-42.

Esposito, John L. 1982. Women in Muslim Family Law. Syracuse, NY: Syracuse University Press.

Galanter, Marc. 1981. "Justice in Many Rooms: Courts, Private Ordering, and Indigenous Law." Journal of Legal Pluralism and Unofficial Law 13, no. 19: 1-47.

Hallaq, Wael. 2009. Sharia: Theory, Practice, Transformations. Cambridge, UK: Cambridge University Press.

. 2012. The Impossible State: Islam, Politics, and Modernity's Moral Predicament. New York: Columbia University Press.

Hussin, Iza. 2017. "Citing Gender: Constituting the Muslim Woman in Malaysia." Cultural and Social History 14, no. 4: 513-25.

Jones, Jones. 2010. “'Signs of Churning': Muslim Personal Law and Public Contestation in Twenty-first Century India." Modern Asian Studies 44, no. 1: 175-200. 
2019. "Where Only Women May Judge: Developing Gender-Just Islamic Laws in India's All-Female 'Sharī'ah Courts."' Islamic Law and Society 26, no. 4: 437-66.

2020. "Towards a Muslim Family Law Act? Debating Muslim Women's Rights and the Codification of Personal Laws in India." Contemporary South Asia 28, no. 1: 1-14.

Lemons, Katherine. 2017. "Paying for Kinship: Muslim Divorce and the Privatization of Insecurity." History of the Present 7, no. 2: 197-218.

2019. Divorcing Traditions: Islamic Marriage Law and the Making of Indian Secularism. Ithaca, NY: Cornell University Press.

Mahmood, Saba. 2005. Politics of Piety: The Islamic Revival and the Feminist Subject. Princeton, NJ: Princeton University Press.

Madhok, Sumi, Anne Phillips, and Kalpana Wilson, eds. 2013. Gender, Agency, and Coercion: Thinking Gender in Transnational Times. Basingstoke, UK: Palgrave Macmillan.

Mehdi, Rubya. 2017. "Lady Judges of Pakistan: Embodying the Changing Living Tradition of Islam." In Women Judges in the Muslim World: A Comparative Study of Discourse and Practice, edited by Nadia Sonneveld and Monika Lindbekk, 204-36. Leiden: Brill.

Mir-Hosseini, Ziba. 2015. "Muslim Legal Tradition and the Challenge of Gender Equality." In Men in Charge: Rethinking Authority in Muslim Legal Tradition, edited by Ziba Mir Hosseini, Mulki Al-Sharmani and Jana Rumminger, 13-43. London: Oneworld.

Moore, Erin P. 1993. "Gender, Power, and Legal Pluralism: Rajasthan, India." American Ethnologist 20, no. 3: 522-42.

Nader, Laura. 1993. "Controlling Processes in the Practice of Law: Hierarchy and Pacification in the Movement to Re-form Dispute Ideology." Ohio State Journal on Dispute Resolution 9, no. 1: 1-25.

Niaz, Noorjehan Safia. 2016. Women's Shariah Court, Muslim Women's Quest for Justice. Chennai: Notion Press.

Nurlaelawati, Euis, and Arskal Salim. 2013. "Gendering the Islamic Judiciary: Female Judges in the Religious Courts of Indonesia." Majalah Al-jamiah 51, no. 2: 247-78.

Peletz, Michael G. 2002. Islamic Modern: Religious Courts and Cultural Politics in Malaysia. Princeton, NJ: Princeton University Press.

— 2020. Sharia Transformations: Cultural Politics and the Rebranding of an Islamic Judiciary. Berkeley: University of California Press.

Phillips, Anne. 2015. "Religion: Ally, Threat or Just Religion." Religion, Secularism and Constitutional Democracy, edited by Jean L. Cohen and Cecile Laborde, 47-65. New York: Columbia University Press.

Presser, Lois, and Emily Gaarder. 2000. "Can Restorative Justice Reduce Battering? Some Preliminary Considerations.” Social Justice 27, no. 1: 175-95.

Punwani. Jyoti. 2016. "Muslim Women: Historic Demand for Change." Economic and Political Weekly 52, no. 34: 12-15.

- 2018. "Triple Talaq Judgment and After." Economic and Political Weekly 53, no. 17: 12-16.

Randeria, Shalini. 2006. "Entangled Histories: Civil Society, Caste Solidarities, and Legal Pluralism in Post-Colonial India." In Civil Society: Berlin Perspectives, edited by John Keane, 213-42. New York: Berghen Books.

Redding, Jeffrey A. 2014. "The Case of Ayesha, Muslim Courts and the Rule of Law: Some Ethnographic Lessons for Legal Theory." Modern Asian Studies 48, no. 4: 940-85.

Risman, Barbara J. 2004. "Gender as a Social Structure: Theory Wrestling with Activism." Gender $\mathcal{F}^{8}$ Society 18, no. 4: 429-50.

Sharafi, Mitra. 2014. Law and Identity in Colonial South Asia: Parsi Legal Culture, 1772-1947. Cambridge, UK: Cambridge University Press.

Solanki, Gopika. 2011. Adjudication in Religious Family Laws: Cultural Accommodation, Legal Pluralism, and Gender Equality in India. Cambridge, UK: Cambridge University Press.

Tschalaer, Mengia Hong. 2017. Muslim Women's Quest for Justice: Gender, Law and Activism in India. Cambridge, UK: Cambridge University Press.

Vatuk, Sylvia. 2013. "Islamic Feminism in India: Indian Muslim Women Activists and the Reform of Muslim Personal Law." In Islamic Reform in South Asia, edited by F. Osella and C. Osella, 346-82 Cambridge, UK: Cambridge University Press. 


\section{LAW \& SOCIAL INQUIRY}

Voorhoeve, Maaike. 2014. Gender and Divorce Law in North Africa: Sharia, Custom and the Personal Status Code in Tunisia. London: I. B. Tauris.

2017. "Tunisian Female Judges and the Mobilization of the Emancipative Potential of the Tunisian Family Law." In Women Judges in the Muslim World: A Comparative Study of Discourse and Practice, edited by Nadia Sonneveld and Monika Lindbekk, 204-36. Leiden: Brill.

Wadud, Amina. 1999. Quran and Woman: Rereading the Sacred Text from a Woman's Perspective. New York: Oxford University Press.

— 2015. "The Ethics of Tawhid over the Ethics of Qiwamah." In Men in Charge? Rethinking Authority in Muslim Legal Tradition, edited by Ziba Mir-Hosseini, Mulki Al-Sharmani, and Jana Rumminger, 256-74. London: Oneworld

Yuksel, Edip, al-Shaiban, Layth Saleh, and Martha Schulte-Nafeh. 2007. Qur'an: A Reformist Translation. Tuscon, AZ: Brainbow Press. 